\title{
Assessment of Variability among Flax Type Linseed Genotypes (Linum usitatissimum L.) of Chhattisgarh Plains
}

\author{
Sonal Upadhyay", Nandan Mehta and Ashish Kumar Tiwari
}

Department of Genetics and Plant Breeding, College of Agriculture, Raipur Indira Gandhi

Krihi Vishwavidyalaya, Raipur - 492012 (Chhattisgarh), India

*Corresponding author

\section{A B S T R A C T}

\begin{tabular}{|l|}
\hline Ke y w o r d s \\
$\begin{array}{l}\text { Flax type linseed } \\
\text { genotypes, } \\
\text { Variability }\end{array}$ \\
\hline Article Info \\
\hline $\begin{array}{l}\text { Accepted: } \\
\text { 20 May } 2019 \\
\text { Available Online: } \\
\text { 10 June } 2019\end{array}$ \\
\hline
\end{tabular}

\section{Introduction}

The name Linum originated from "lin" or "thread" and the species name Usitatissimum is a Latin word meaning "most useful". It is also called flaxseed or linseed when it is used as oilseed and referred to as fiber flax or just flax (in Europe) when it is used for fiber (Vaisey-Genser and Diane, 2003). Linseed or flax is one of the oldest crops cultivated by man. Linseed is an annual herb with 6,0007,000 years planting history. Flaxseed is rich in fat, protein and dietary fibre. An analysis of brown flax averaged $41 \%$ fat, $20 \%$ protein, $28 \%$ total dietary fibre, $7.7 \%$ moisture and $3.4 \%$ ash, which is the mineral-rich residue left after samples are burned. The protein content of the seed decreases as the oil content increases. The oil content of seed generally varies from 33 to 45 per cent (Gill, 1987). If we consider the nutritional properties of linseed, the foremost thing to be mentioned is the presence of a high amount of omega fatty acids. There are two groups of omega fats: omega- 3 and omega- 6 fatty acids. Linolenic acid, eicosapentaenoic acid (EPA) and docosahexanoic acid (DHA) are three types of omega-3 fatty acids and are nutritionally important. Flaxseed is a rich source of dietary fiber (accounting 28\%), both soluble as well as insoluble fibers. Flaxseed is the richest source of plant lignans (Thompson 
et al., 1991). Besides having such a rich nutritional profile, the edible use of linseed in the country remains stagnant and the health benefits of the crop could not reach to people's diet.

The 'Linen' obtained from flax fibre is one of the best raw materials for textile.The best grades are used for linen fabrics such as damasks, lace and sheeting. Flax fibre is strong, non-lignified, soft, flexible, lustrous, shining, pale yellow colour and possesses high water absorbency quality. Flax contains $80-90 \%$ cellulose. It is valued for strength and durability excelling cotton and stronger than cotton, rayon or wool

\section{Materials and Methods}

The experimental materials comprised of 25 lines of flax type linseed genotypes in the germplasm accession of AICRP on linseed, Indira Gandhi Krishi Vishwavidyalaya, Raipur. The genotypes were obtained by phenotypic selection from the linseed germplasm pool. The experiment was laid out in a randomized block design with three replications. The entries were sown in one row each of $3 \mathrm{~m}$ length with spacing of $30 \mathrm{~cm}$ between rows and $10 \mathrm{~cm}$ approximately between the plants the recommended packages of practices were followed for raising a healthy crop and all necessary plant protection measures were taken to control the pest and diseases. The observations were recorded for different qualitative and quantitative characters in linseed (based on Catalogue on linseed germplasm, Project Coordinating Unit (Linseed), C.S.A.U.A.\&T. campus, Kanpur, 2010

\section{Results and Discussion}

The purpose of the present investigation was to generate information on morphological traits, which can throw light on the chances of further improvement of these genotypes either through selection or through hybridization programme. Analysis of variance for yield and yield attributing traits in linseed have been given in Table 1 .

The table 2 indicated that the mean sum of squares due to genotypes was found to be significant for all the traits except for number of seeds per capsule. This indicates the presence of variability among linseed genotypes for yield and its contributing traits.

\section{Genetic variability}

Results of genetic variability revealed that in general, phenotypic coefficient of variation for all the traits under study was higher to their corresponding genotypic coefficient of variation indicating substantial influence of environment in the expression of characters (Table 2).

\section{Estimation of genetic variability parameters}

The information based on the nature of extent of genetic variation for desirable traits in selection for improvement of the crop.

The knowledge of genotypic and phenotypic coefficient of variation is being useful in designing selection criteria for variable population. Genotypic \& phenotypic coefficient of variation of different characters is presented in the table.

\section{Phenotypic and genotypic coefficient of variability}

In general, it was noted that the value of phenotypic coefficient of variation were higher than genotypic coefficient of variation. The highest GCV was recorded for number of seeds per plant (17.16\%) followed by seed yield per plant (16.39\%), number of seeds per 
capsule (15.21\%), 100 seed weight (14.90\%), number of capsules per plant $(8.61 \%)$, plant height (4.90\%), days to $50 \%$ flowering $(3.80 \%)$ and days to maturity (2.07\%).. The highest PCV was recorded for number of seeds per plant $(18.30 \%)$ followed by seed yield per plant $(18.12 \%)$, number of seeds per capsule $(16.80 \%), 100$ seed weight $(16.20 \%)$, number of capsules per plant $(12.45 \%)$, plant height $(5.17 \%)$, days to $50 \%$ flowering(3.94\%) and days to maturity $(2.12 \%)$.
The magnitude of PCV was higher than the corresponding GCV for all the traits. This might be due to the interaction of the genotypes with the environment to some degree or environmental factor influencing the expression of these traits. Close correspondence between phenotypic and genotypic coefficient of variation were observed i.e. sufficient variability among the traits is present among the genotype. Hence, the ample scope of improvement of these traits (Fig. 1).

Fig.1 Graphical representation of coefficient of variation for yield and its attributing traits in linseed

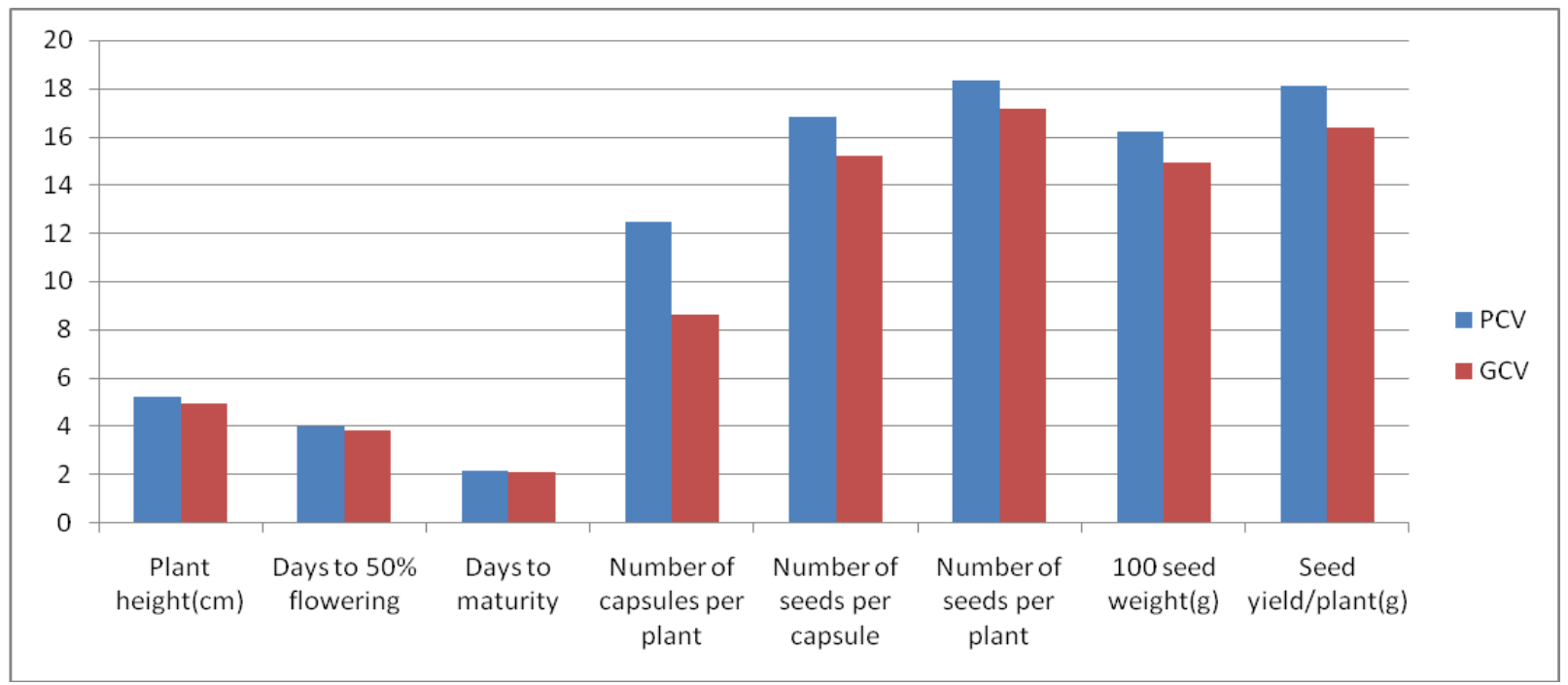

Table.1 Analysis of variance for yield and its contributing traits in flax type linseed genotypes at Raipur (C.G.)

\begin{tabular}{|c|c|c|c|c|c|c|c|c|c|c|}
\hline \multirow{2}{*}{$\begin{array}{l}\text { S. } \\
\text { no. }\end{array}$} & \multirow{2}{*}{$\begin{array}{l}\text { Source of } \\
\text { variation }\end{array}$} & \multirow[t]{2}{*}{ Df } & \multicolumn{8}{|c|}{ Mean sum of squares } \\
\hline & & & $\begin{array}{l}\text { Plant } \\
\text { height }\end{array}$ & $\begin{array}{l}\text { Days to } \\
50 \% \\
\text { flowering }\end{array}$ & $\begin{array}{l}\text { Days to } \\
\text { maturity }\end{array}$ & $\begin{array}{l}\text { No.of } \\
\text { capsules/plant }\end{array}$ & $\begin{array}{l}\text { No.of } \\
\text { seeds } \\
\text { /capsule }\end{array}$ & $\begin{array}{l}\text { No.of } \\
\text { seeds } \\
\text { /plant }\end{array}$ & $\begin{array}{l}100 \\
\text { seed } \\
\text { weight }\end{array}$ & $\begin{array}{l}\text { Seed } \\
\text { yield/pl } \\
\text { ant }\end{array}$ \\
\hline 1 & RMSS & 2 & 2.40 & 0.29 & 0.71 & 4.84 & 0.62 & 81.68 & $0.19^{* *}$ & $43.55^{*}$ \\
\hline 2 & $\begin{array}{l}\text { Genotypes } \\
\text { MSS }\end{array}$ & 24 & $\begin{array}{l}57.20^{*} \\
*\end{array}$ & $57.30^{* *}$ & $61.02^{* *}$ & $15.12^{* * *}$ & 4.07 & $\begin{array}{l}2302.68 * \\
*\end{array}$ & $0.75 * *$ & $\begin{array}{l}88.15^{*} \\
*\end{array}$ \\
\hline 3 & EMSS & 48 & 2.08 & 0.17 & 0.20 & 4.03 & 0.17 & 237.76 & 0.01 & 6.74 \\
\hline
\end{tabular}

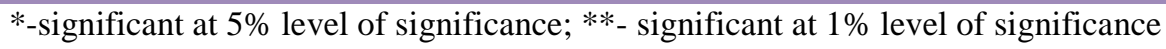


Table.2 Genetic parameters of variation for yield and yield contributing characters in flax type genotypes of linseed

\begin{tabular}{|c|c|c|c|c|c|c|c|c|c|}
\hline \multirow[t]{2}{*}{ s.no. } & \multirow{2}{*}{$\stackrel{\text { parameters }}{\longrightarrow}$} & \multirow[t]{2}{*}{ Mean } & \multicolumn{2}{|l|}{ Range } & \multirow[t]{2}{*}{$\begin{array}{l}\text { Critical } \\
\text { difference }\end{array}$} & \multicolumn{2}{|c|}{$\begin{array}{l}\text { Coefficient of } \\
\text { variation }\end{array}$} & \multirow[t]{2}{*}{$\mathbf{H}^{2}(\mathrm{bs}) \%$} & \multirow{2}{*}{$\begin{array}{l}\text { GA as } \\
\text { percent } \\
\text { of mean }\end{array}$} \\
\hline & & & Max. & Min. & & Pev & Gev & & \\
\hline 1 & Plant height $(\mathrm{cm})$ & 83.37 & 100.50 & 80.90 & 3.18 & 5.17 & 4.90 & 0.89 & 9.58 \\
\hline 2 & $\begin{array}{l}\text { Days to } 50 \% \\
\text { flowering }\end{array}$ & 61.36 & 63.00 & 57.33 & 0.19 & 3.94 & 3.80 & 0.98 & 4.01 \\
\hline 3 & Days to maturity & 110.48 & 118.00 & 103.00 & 0.13 & 2.12 & 2.07 & 0.87 & 7.07 \\
\hline 4 & $\begin{array}{l}\text { Number of } \\
\text { capsules per plant }\end{array}$ & 22.32 & 28.33 & 17.67 & 4.38 & 12.45 & 8.61 & 0.47 & 93.48 \\
\hline 5 & $\begin{array}{l}\text { Number of seeds } \\
\text { per capsule }\end{array}$ & 6.88 & 9.00 & 4.69 & 0.93 & 16.80 & 15.21 & 0.87 & 30.21 \\
\hline 6 & $\begin{array}{l}\text { Number of seeds } \\
\text { per plant }\end{array}$ & 152.82 & 201.90 & 98.22 & 34.04 & 18.30 & 17.16 & 0.74 & 27.63 \\
\hline 7 & 100 seed weight $(\mathrm{g})$ & 1.00 & 1.53 & 0.43 & 0.30 & 16.20 & 14.90 & 0.80 & 47.92 \\
\hline 8 & Seed yield/plant $(\mathrm{g})$ & 15.53 & 23.69 & 5.05 & 5.61 & 18.12 & 16.39 & 0.83 & 59.67 \\
\hline
\end{tabular}

\section{Heritability}

The nature and extent of inherent capacity of a genotype for a character is an important parameter that determines the extent of any crop species. Genetic improvement of any character is difficult without having sufficient heritability. Estimates of heritability give some idea about the gene action involved in the expression of various polygenic traits. The selection should be effective if variance due to additive genes, estimated in terms of heritability. Heritability estimates remain extremely useful in the inheritance studies of quantitative traits.

The highest heritability estimate was observed for days to $50 \%$ flowering (98\%) followed by plant height $(89 \%)$, days to maturity $(87 \%)$ and seed yield per plant (83\%) indicating predominance of additive gene action in the expression of these traits. This being fixable in nature considerable progress is expected through appropriate selection scheme to be adopted. The findings are in agreement with the findings for days to $50 \%$ flowering by Rao and Singh (1985); Singh (2001); Adugna and Labuschagne (2004); Ahemad et al., (2014), for plant height Muhammad et al., (2003), for number of capsules per plant Muhammad et al., (2003); Kandil et al., (2012), for 1000 seed weight Muhammad et al., (2003); Kandil et al., (2012); Ahemad et al., (2014) and for seed yield per plant Muhammad et al., (2003); Kandil et al., (2012).

\section{Genetic Advance (GA) as percent of mean}

Genetic advance was calculated as \% of mean. Genetic advance and heritability are the major factor in the improvement of mean genotypic value of selected plants over the parental population.

The success of genetic advance depends on genetic variability, heritability, selection intensity 
The highest amount of genetic advance as percent of mean was observed for number of capsules per plant $(93.48 \%)$ followed by seed yield per plant (59.67) and 100 seed weight $(47.92 \%)$

The minimum value of genetic advance was seen for days to $50 \%$ flowering $(4.01 \%)$

In conclusion, it was clear from the analysis of variance that variability existed among the yellow seeded linseed genotypes taken under study. The significant genetic variability in any breeding material is a prerequisite as it does not only provide a basis for selection but also provide some valuable information regarding selection of diverse parents for use in hybridization programme.

\section{References}

Bhateria, S., Sood, S. and Pathania, A. 2006. Genetic analysis of quantitative traits across environments in linseed (Linum usitatissimum L.). Euphytica 150(12):185-194.

Diederichsen, A. 2001. Comparison of genetic diversity of flax (Linum usitatissimum L.) between Canadian cultivars and a world collection. Plant Breeding. 120: 360-362.

Diederichsen, A. and Fu, Y. B. 2006. Phenotypic and molecular (RAPD) differentiation of four intraspecific groups of cultivated flax (Linum usitatissimum L. sub sp. usitatissimum). Genetic Resources and Crop Evolution. 53: 77-90.

Gupta, G.P., Mathur, B.P. and Khan, A.R. 1964. Studies on the performance of linseed Varieties. Indian oilseeds journal, 8: 9-10.

Meagher, L.P., Beecher, G.R., Flanagan, V.P. and Li, B.W. 1999. Isolation and characterization of the lignans, isolariciresinol and pinoresinol, in flaxseed meal. Journal of Agricultural Food Chemistry 47 (8): 3173-3180

Mirza, S. H., Daulotun, N., Islam, S. and Nessa, D. 1996. Genetic of inter Relationships between seed yield and its components in linseed. Bangladesh Journal of botany, 25: 197-201.

Mishra, A. K. and Yadav, L. N. 1999. Genetic parameters and association analysis in linseed. Indian journal of agricultural research, 33:113-118.

Pali, V. 2013. and Mehta, N. 2013. Studies on Genetic Variability, Correlation and Path Analysis for yield and its attributes in Linseed (Linum usitatissimum L.). Plant Archive. 13(1): 223-227.

Satapathi, D., Mishra, R.C. and Panda, B.S. 1989. Variability, correlation and path coefficient analysis in linseed. Journal of Oilseeds Research, 4(1): 28-34

Verma, O. P. 1996. Genetic divergence in linseed (Linum usitatissimum L.). Journal of Oilseeds research, 13 (2): 225-228.

\section{How to cite this article:}

Sonal Upadhyay, Nandan Mehta and Ashish Kumar Tiwari. 2019. Assessment of Variability among Flax Type Linseed Genotypes (Linum usitatissimum L.) of Chhattisgarh Plains. Int.J.Curr.Microbiol.App.Sci. 8(06): 2633-2637. doi: https://doi.org/10.20546/ijcmas.2019.806.316 